Yüzüncü Y1l Üniversitesi
Fen Bilimleri Enstitüsü Dergisi
http://dergipark.gov.tr/yyufbed

Research Article

\title{
Comparison of Environment Noise Intensity Using Ios and Android Based Sound Measurement Applications and Commercial Sound Measurement Devices and Obtaining the Measurement Uncertainty
}

\author{
İsrafil ŞABíKOĞLU*1, Duygu AKBABA ŞABİKOĞLU² \\ ${ }^{1}$ Manisa Celal Bayar University, Faculty of Science and Letters, Department of Physics, Manisa, Turkey \\ ${ }^{2}$ Manisa Celal Bayar University, Institute of Natural and Applied Science, Manisa, Turkey
}

İsrafil ŞABİKOĞLU, ORCID No: 0000-0002-2260-3326, Duygu AKBABA ŞABİKOĞLU, ORCID No: 00000002-5608-2813

*Corresponding author e-mail: israfil.sabikoglu@cbu.edu.tr

\section{Article Info}

Recieved: 10.03.2021

Accepted: 11.05.2021

Published August 2021

DOI: $10.53433 /$ yyufbed.894712

Keywords

Android,

Ios,

Commercial devices,

Mobile application,

Sound intensity,

Uncertainty

\begin{abstract}
In this study, sound measurement between ios and android operating system based mobile phones (Soundmeter, Decibel X) and commercial sound measurement devices (Cem dt8852, Svantek sv104) was tested. Sound measurement intensities and energies were determined, measurement uncertainties of ios and android devices according to the application were determined. Measurements were carried out at the same time in the indoor and outdoor environment. Iphone 7+ (Ios operation system) and Samsung note 8 (Andorid operation system) used. Significant sound measurement differences were obtained between the two different mobile phone applications. There was no significant difference between commercial measurement devices. Commercial measuring devices were calibrated and can be used as reference devices. Using these devices, it was observed that ios and android-based applications receive faulty measurements on average between $10-20 \%$. As a result of the measurements taken with the applications, it was determined that the measurement uncertainty is in the range of approximately $\pm 4-5 \mathrm{~dB}$.
\end{abstract}

\section{Ortam Gürültü Şiddetinin, Ios ve Android Tabanlı Ses Ölçüm Uygulamaları ile Ticari Ses Ölçüm Cihazları Kullanılarak Karşılaştırılması ve Ölçüm Belirsizliğinin Eıde Edilmesi}

\section{Makale Bilgileri}

Geliş: 10.03.2021

Kabul: 11.05.2021

Yayınlanma Ağustos 2021

DOI: $10.53433 /$ yyufbed.894712

\author{
Anahtar kelimeler \\ Android, \\ Ios, \\ Ticari cihazlar, \\ Mobil uygulama, \\ Ses şiddeti, \\ Belirsizlik
}

Öz: Bu çalışmada, ios ve android işletim sistemi tabanlı cep telefonlarındaki ses ölçüm uygulamaları ile (Soundmeter, Decibel X), ticari ses ölçüm cihazları (Cem dt8852, Svantek sv104) arasındaki ses ölçümü test edilmiştir. Ses ölçüm şiddetleri ve enerjileri belirlenmiş, ios ve android cihazların, uygulamaya göre ölçüm belirsizlikleri belirlenmiştir. Ölçümler iç ve dış ortamda aynı anda gerçekleştirilmiştir. Ios kullanan iphone $7+$ ve android kullanan samsung note 8 cihazı kullanılmıştır. İki farklı cep telefonu uygulamaları arasında önemli ses ölçüm farkları elde edilmiştir. Ticari ölçüm cihazları arasında ise önemli bir fark bulunmamıştır. Ticari ölçüm cihazları kalibre edilmiş olduğundan, referans cihaz olarak kullanilabilir. $\mathrm{Bu}$ cihazlar kullanılarak, ios ve android tabanlı uygulamaların ortalama \%10-20 arasında hatalı ölçüm aldığı gözlenmiştir. Uygulamalar ile alınan ölçümler sonucunda, ölçüm belirsizliği yaklaşık $\pm 4-5 \mathrm{~dB}$ aralığında olduğu tespit edilmiştir. 


\section{Introduction}

Sound is periodic pressure changes in the atmosphere that can be perceived by our ears. Sound is a form of energy that spreads in waves. Any vibrating object pushes and compresses the air in front of it, and there is a sudden drop in pressure behind the object. At the same time, the air in the back fills this space. With this movement, neighboring molecules vibrate in the same way and vibrations are emitted as a result of the chain movement. This distribution is performed as a sine wave. Such pressure waves in the air reach the ear and vibrate the eardrum. Nerves turn these vibrations into electrical signals and transmit them to the brain, so that the sound in the environment is heard. Sound can be spread in any environment (Serway et.al. ,1999; Serway \& Jewet, 2010).

Sound from a source has a certain wavelength, frequency, period, intensity and power. Sounds from different sources can interfere with each other and sound waves of very different frequency and intensity may occur. The measurable intensity of the sound is called decibels (dB). The intensity of the sound is the amount of power passing through the unit surface perpendicular to the separation direction of the wave (Young \& Freedman, 2011).

The formula for sound intensity is as follows (Young et.al., 2013);

$$
\beta=10 \log _{10}\left(\mathrm{I} / 10^{-12}\right)
$$

where, I is sound intensity (watt $/ \mathrm{m}^{2}$ ). In the SI unit system, the unit of intensity of the sound is given in decibels $\left(\mathrm{dB}-\mathrm{watt} / \mathrm{m}^{2}\right)$.

Various sound/noise intensities heard around us are given in Figure 1.

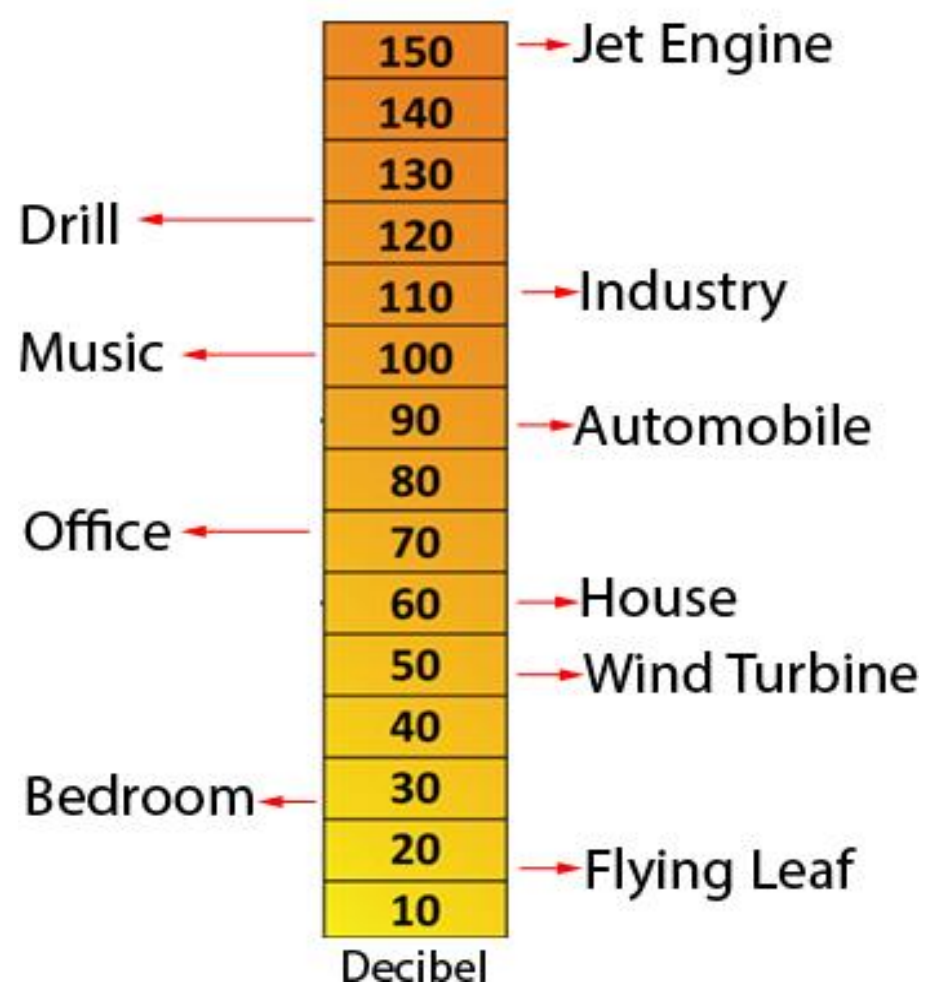

Figure 1. Various intensity of the noises/sounds.

Sound can move at different speeds according to separation medium. The speed of sound separation in a certain environment is calculated as follows (Mazda, 1993);

$$
v=\sqrt{\frac{e}{\rho}}
$$


Where, e is elastic modulus of separation medium, and $\rho$ is density. Sound spreads faster in solids and liquids than gases. Under normal conditions, the speed of sound in air is $343 \mathrm{~m} / \mathrm{s}$.

Since the intensity of a sound separation in the air is determined logarithmically, it is not possible to perform mathematical direct operations with the decibel unit intensity. Therefore, the decibel sound intensity must be converted into known sound intensity units. A set of semi-empirical formulas can be produced with the sound intensity that can be converted into watt $/ \mathrm{m}^{2}$ with formula (1). Thus, the power $(\mathrm{P})$ and energy (E) of the sound in the environment can be calculated by the following equations;

$$
\begin{aligned}
& \mathrm{P}=\mathrm{I} . \mathrm{s} \\
& \mathrm{E}=\mathrm{P} . \Delta \mathrm{t}
\end{aligned}
$$

In here, I is the intensity of the sound from (1) equation (watt $\left./ \mathrm{m}^{2}\right), \mathrm{s}$ is the surface cross-sectional area of the microphone on the sound recording device $\left(\mathrm{m}^{2}\right)$, and $\Delta \mathrm{t}$ is timekeeping of the sound measurement (s).

Also, the pressure change in the sound can be written as;

$$
\Delta p=\sqrt{2 \rho v I}
$$

In here, $\rho$ is density of the medium, and $\mathrm{v}$ is velocity of the sound.

Internationally, sound intensities are examined under 4 groups. Among these groups called A, $\mathrm{B}, \mathrm{C}$ and $\mathrm{D}$, the $\mathrm{dB}(\mathrm{A})$ group is used for the measurement of noise levels perceived by the human ear (TSE, 2014), dB (D) is used to determine the sound levels of jet engines, which are much louder. A sound level measuring device (Decibelmeter) is needed to measure the noise around us. These devices can determine the intensity of the sound in $\mathrm{dB}$. On the other hand, mobile phones can function like sound meters. Environment sound can be recorded with microphones and applications on mobile phones (ANSI, 2007).

In our environment, sounds above $60 \mathrm{~dB}$ are called noise and can have significant side effects when exposed to it constantly. Noise is a problem that affects everyone. It has been determined by many researchers that people who stay in high-noise environments for a long time have permanent hearing losses (Sriwattanatamma \& Breysse, 2000; Pienskowski et.al., 2013). According to some studies, high sound exposure can cause an average of $16 \%$ hearing loss. In addition, according to a study conducted in China, most of the youth working under the age of 16 are exposed to 92dB of loudness and causes serious hearing loss (O'malley et.al. 2009; Sheppard et.al., 2020; Sun et.al., 2021).

According to Occupational Safety and Health Administration (OSHA) and the National Institute for Occupational Safety and Health (NIOSH) organizations, the maximum sound intensity that people can be exposed to has been determined. The maximum sound intensity levels for 8 hours of working per day are specified as 85dB (NIOSH) and 90dB (OSHA) (NIOSH, 1998; May, 2000; OSHA, 2013).

In Turkey, the sound exposure values are determined in accordance with law no. 6331 occupational health and safety law. According to No. 6331 law, it is specified as a maximum of $85 \mathrm{db}$ for 8 hours of working per a day (TOG, 2012).

According to some researches, environment sound measurements can be taken with ios and android based applications. In these studies, A type and $\mathrm{C}$ type environment sound measurements were taken using different mobile applications and the differences between these applications were shown (Maisonneuve et.al., 2010; Kanhere, 2013; Anonymous, 2013b). It has been reported that there is an average of $2 \mathrm{~dB}$ difference between mobile applications (Kardousb et.al., 2014). In another study, environment sound analysis was performed with 100 different mobile phones. It has been stated that Ios-based mobile applications are superior to android-based applications and it has been shown that there is an average of $1 \mathrm{~dB}$ difference (Murphy et.al., 2016). In addition, in another study using both mobile phones and tablets, it has been stated that ios-based applications work more stably and there are average 2dB differences (Maisonnuve et.al., 2009; Kanio, 2010; D’Hondt et.al., 2013).

In present work, the sound levels in indoor and outdoor locations were determined in $\mathrm{dB}$ unit with two different sound measurement applications based on Ios and Android and two different 
commercial sound measurement devices that calibrated (internationally traceable, accredited). Measurement uncertainties of ios and android based mobile phones were calculated. The energy, power and pressure change of the sound were calculated from the obtained sound intensity values.

\section{Materials and Methods}

Smart phones (Iphone 7+ for ios-based and Samsung Note8 for android-based) with two different operating systems used in the experimental study. Soundmeter (developed by Faber Acustical) and Decibel X (developed by SkyPaw Ltd.) used in both phones as sound measurement applications. Commercial sound meters Cem DT8852 and Svantek SV104 used. Commercial sound measuring devices were calibrated by an accredited organization and measurement uncertainties were given as $0.5 \mathrm{~dB}$ and $1 \mathrm{~dB}$ respectively. Thus, 4 different measurement methods were defined (iphone $7+$, samsung note8, Cem, and Svantek).

In indoor and outdoor locations, 10 measurements were taken in 5 seconds $(\Delta t=5 \mathrm{~s})$ at the same time. The mean and standard deviation of the measurements were calculated. In addition, using the relevant equations, measurement intensity, energy and pressure calculated. The measurement chart is given in Figure 2.

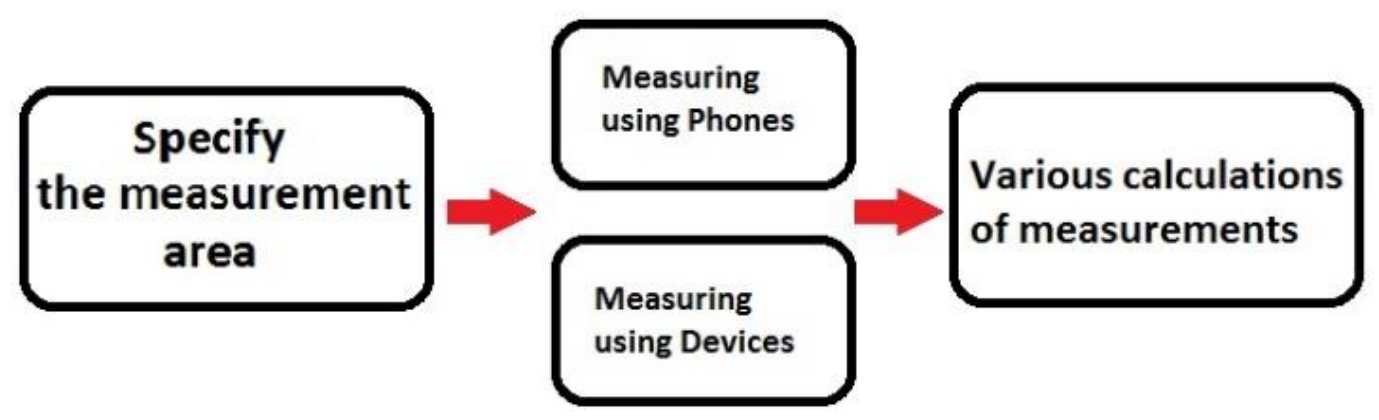

Figure 2. The measurement chart.

Measurements taken from various areas of a university. These areas are named as follows; "Entrance, Canteen/Dining Hall, Park/Resting Area, Classroom, Laboratory". In addition, a box covered with sound insulation material was designed and the muteness measurements of the devices were taken in this box. When there was almost no noise in the environment, the sound data measured by the devices were evaluated in this box.

Sound intensity measured in decibels was converted to I (sound intensity) using equation (1). Later, the $\mathrm{P}$ power of the sound intensities was calculated from the formula (3), and the E energies from the formula (4). In addition, the pressure variations of the sound were calculated using the formula (5). For experiments in air environment, $\rho$; the air density $\left(1,2 \mathrm{~kg} / \mathrm{m}^{3}\right)$ and $\mathrm{v}$; the speed of sound in the air $(343 \mathrm{~m} / \mathrm{s})$ were used. The measuring range (timekeeping) $\Delta \mathrm{t}$ was evaluated as $5 \mathrm{~s}$.

In addition, the surface cross-sectional areas, $\mathrm{s}=0.45^{*} 10^{-6} \mathrm{~m}^{2}$ (for Apple iphone $7+$ ), $\mathrm{s}=6.5^{*} 10^{-7} \mathrm{~m}^{2}$ (for Samsung Note8), $\mathrm{s}=9.499 * 10^{-5} \mathrm{~m}^{2}$ (for Cem DT8852), and $\mathrm{s}=1.26^{*} 10^{-5} \mathrm{~m}^{2}$ (for Svantek SV104) were determined from the technical information of the related devices (for iphone and samsung, mic chip sizes are taken, for Cem and Svantek, device manufacturers declarations were taken).

Commercial sound measuring devices used in the study are shown in Figure 3. 


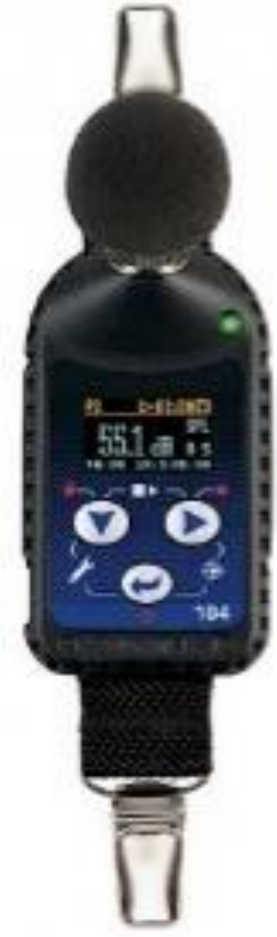

(a)

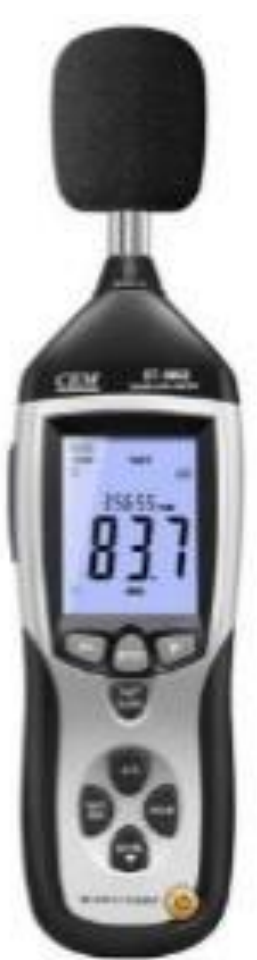

(b)

Figure 3. Commercial sound measurement devices, (a) Svantek SV104, and (b) Cem DT8852.

\section{Results and Discussion}

The sound intensity spread in the environment is the sounds that arise from multiple different sources and have different frequencies. Therefore, the sound intensity from each sound source can also be different. Both ios, android-based phones and Cem and Svantek sound measuring devices convert the sound energy that they received from the environment into electronic voltage values. They all display their instantaneous sound values in $\mathrm{dB}$ unit. Using these data, the energy, power and pressure difference values of the sound are shown in Table 1.

According to Table 1; sound meter application measured the highest sound value in both ios and android based phones in the canteen and parking area. Values over $80 \mathrm{~dB}$ were recorded in these areas as well as the sound intensities I in unit of $\left(w a t t / \mathrm{m}^{2}\right)$ were calculated at highest. Similar results were obtained with the Decibel X application. On the other hand, the lowest values were observed in the measurements inside the insulation box. However, the measurements inside the insulation box evaluated separately according to the measurements in other areas. Therefore, it can be said that the lowest sound measurement location is the laboratory according to both the sound meter and the decibel $\mathrm{x}$ application.

Commercial measuring devices also recorded the highest and lowest sound values in the canteen and laboratory, respectively. However, there was a measurement difference between commercial sound meters and mobile applications sound data, ranging from an average of 10-20\%. Measurements taken with both ios and android-based phones recorded an average of 10-20\% more than the measurements taken by commercial sound meters.

Measurements taken in an isolated box can be defined as electrical noises that can be measured when there is almost no sound in the environment. The point to note here is that there is an almost $50 \%$ difference between Cem and Svantek devices. Although the uncertainties of both devices are almost the same, there is a difference close to $50 \%$ in the measurement's unit in $\mathrm{dB}$. It is thought that this situation may be electronic noise caused by different electronic circuit elements used in Cem and Svantek devices. Sound values (in $\mathrm{dB}$ units) recorded by mobile applications and devices in the isolation box are given in Figure 4. 
Table 1. Calculated of the average sound intensity in $\mathrm{dB}$ and watt $/ \mathrm{m}^{2}$ unit, power $(\mathrm{P})$, energy $(\mathrm{E})$, and pressure difference $(\Delta p)$.

\begin{tabular}{|c|c|c|c|c|c|c|c|}
\hline $\begin{array}{r}\text { Measurement } \\
\text { Area }\end{array}$ & Device & Application & $\begin{array}{l}\mathrm{dB}(\mathrm{A}) \\
\text { (average) }\end{array}$ & $\begin{array}{l}\mathrm{I}\left(\mathrm{watt} / \mathrm{m}^{2}\right) \\
\mathrm{x} 10^{-6}\end{array}$ & $\begin{array}{l}\mathrm{P} \text { (Watt) } \\
\mathrm{x} 10^{-13}\end{array}$ & $\begin{array}{l}\text { E(Joule) } \\
\times 10^{-11}\end{array}$ & $\begin{array}{l}\Delta \mathrm{P} \\
\left(\mathrm{N} / \mathrm{m}^{2}\right) \\
\mathrm{x} 10^{-3}\end{array}$ \\
\hline \multirow{6}{*}{ Entrance } & \multirow{2}{*}{ Iphone 7+ } & Sound meter & 80.21 & 104.954 & 472.294 & 23.61 & 293.935 \\
\hline & & Decibel X & 61.72 & 1.485 & 6.687 & 0.334 & 34.975 \\
\hline & \multirow{2}{*}{$\begin{array}{l}\text { Samsung } \\
\text { Note } 8\end{array}$} & Sound meter & 77 & 50.118 & 325.772 & 16.288 & 203.119 \\
\hline & & Decibel X & 62.2 & 1.659 & 10.787 & 0.539 & 36.962 \\
\hline & $\begin{array}{l}\text { Cem } \\
\text { DT8852 }\end{array}$ & & 58.35 & 0.683 & 650.0 & 32.482 & 23.728 \\
\hline & $\begin{array}{l}\text { Svantek } \\
\text { SV104 }\end{array}$ & & 57.43 & 0.553 & 69.4 & 3.472 & 21.343 \\
\hline \multirow{6}{*}{$\begin{array}{l}\text { Canteen/Dining } \\
\text { Hall }\end{array}$} & \multirow{2}{*}{ Iphone 7+ } & Sound meter & 82.23 & 167.109 & 752.0 & 37.599 & 370.896 \\
\hline & & Decibel X & 71.12 & 12.942 & 58.2 & 2.911 & 103.217 \\
\hline & \multirow{2}{*}{$\begin{array}{l}\text { Samsung } \\
\text { Note } 8 \\
\end{array}$} & Sound meter & 81.16 & 130.617 & 849.0 & 42.45 & 327.908 \\
\hline & & Decibel X & 70.33 & 10.789 & 70.1 & 3.506 & 94.244 \\
\hline & $\begin{array}{l}\text { Cem } \\
\text { DT8852 }\end{array}$ & & 65.3 & 3.388 & 3220 & 160.9 & 52.814 \\
\hline & $\begin{array}{l}\text { Svantek } \\
\text { SV104 }\end{array}$ & & 64.73 & 2.971 & 373.0 & 18.64 & 49.459 \\
\hline \multirow{6}{*}{$\begin{array}{l}\text { Park/Resting } \\
\text { Area }\end{array}$} & \multirow{2}{*}{ Iphone 7+ } & Sound meter & 81.16 & 130.617 & 588.0 & 29.38 & 327.908 \\
\hline & & Decibel X & 74.69 & 29.444 & 132.0 & 6.624 & 155.687 \\
\hline & \multirow{2}{*}{$\begin{array}{l}\text { Samsung } \\
\text { Note } 8\end{array}$} & Sound meter & 82.39 & 173.38 & 1130 & 56.35 & 377.791 \\
\hline & & Decibel X & 72.36 & 17.218 & 112.0 & 5.596 & 119.056 \\
\hline & $\begin{array}{l}\text { Cem } \\
\text { DT8852 }\end{array}$ & & 54.37 & 0.273 & 260.0 & 12.99 & 15.005 \\
\hline & $\begin{array}{l}\text { Svantek } \\
\text { SV104 }\end{array}$ & & 54.41 & 0.276 & 34.6 & 1.732 & 15.075 \\
\hline \multirow{6}{*}{ Classroom } & \multirow{2}{*}{ Iphone 7+ } & Sound meter & 68.49 & 7.063 & 31.8 & 1.589 & 76.252 \\
\hline & & Decibel X & 54.21 & 0.263 & 1.19 & 0.059 & 14.731 \\
\hline & \multirow{2}{*}{$\begin{array}{l}\text { Samsung } \\
\text { Note } 8 \\
\end{array}$} & Sound meter & 68.03 & 6.353 & 41.3 & 2.065 & 72.319 \\
\hline & & Decibel X & 55.15 & 0.327 & 2.13 & 0.106 & 16.415 \\
\hline & $\begin{array}{l}\text { Cem } \\
\text { DT8852 }\end{array}$ & & 44.73 & 0.029 & 28.2 & 1.411 & 4.945 \\
\hline & $\begin{array}{l}\text { Svantek } \\
\text { SV104 }\end{array}$ & & 46.96 & 0.049 & 6.23 & 0.312 & 6.393 \\
\hline \multirow{6}{*}{ Laboratory } & \multirow{2}{*}{ Iphone 7+ } & Sound meter & 64.69 & 2.944 & 13.2 & 0.662 & 49.232 \\
\hline & & Decibel X & 50.51 & 0.112 & 0.506 & 0.025 & 9.621 \\
\hline & \multirow{2}{*}{$\begin{array}{l}\text { Samsung } \\
\text { Note } 8\end{array}$} & Sound meter & 66.1 & 4.073 & 26.5 & 1.323 & 57.909 \\
\hline & & Decibel X & 55.96 & 0.394 & 2.56 & 0.128 & 18.019 \\
\hline & $\begin{array}{l}\text { Cem } \\
\text { DT8852 } \\
\end{array}$ & & 36.22 & 0.004 & 3.98 & 0.198 & 1.856 \\
\hline & $\begin{array}{l}\text { Svantek } \\
\text { SV104 }\end{array}$ & & 39.24 & 0.008 & 1.05 & 0.053 & 2.628 \\
\hline \multirow{6}{*}{ Isolation Box } & \multirow{2}{*}{ Iphone 7+ } & Sound meter & 15.03 & $3.18 * 10^{-5}$ & $14.3 * 10^{-5}$ & $0.72 * 10^{-5}$ & 0.161 \\
\hline & & Decibel X & 8 & $0.63 * 10^{-5}$ & $2.84 * 10^{-5}$ & $0.14 * 10^{-5}$ & $7.2 * 10^{-2}$ \\
\hline & \multirow{2}{*}{$\begin{array}{l}\text { Samsung } \\
\text { Note } 8\end{array}$} & Sound meter & 15.53 & $3.5 * 10^{-5}$ & $23.2 * 10^{-5}$ & $1.16^{*} 10^{-5}$ & $17.1 * 10^{-2}$ \\
\hline & & Decibel X & 7.25 & $0.5 * 10^{-5}$ & $3.45 * 10^{-5}$ & $0.17 * 10^{-5}$ & $6.6^{*} 10^{-2}$ \\
\hline & $\begin{array}{l}\text { Cem } \\
\text { DT8852 } \\
\end{array}$ & & 5.57 & $0.4^{*} * 10^{-5}$ & $343 * 10^{-5}$ & $17.12 * 10^{-5}$ & $5.4 * 10^{-2}$ \\
\hline & $\begin{array}{l}\text { Svantek } \\
\text { SV104 }\end{array}$ & & 3.72 & $0.2 * 10^{-5}$ & $29.6 * 10^{-5}$ & $1.47 * 10^{-5}$ & $4.4 * 10^{-2}$ \\
\hline
\end{tabular}




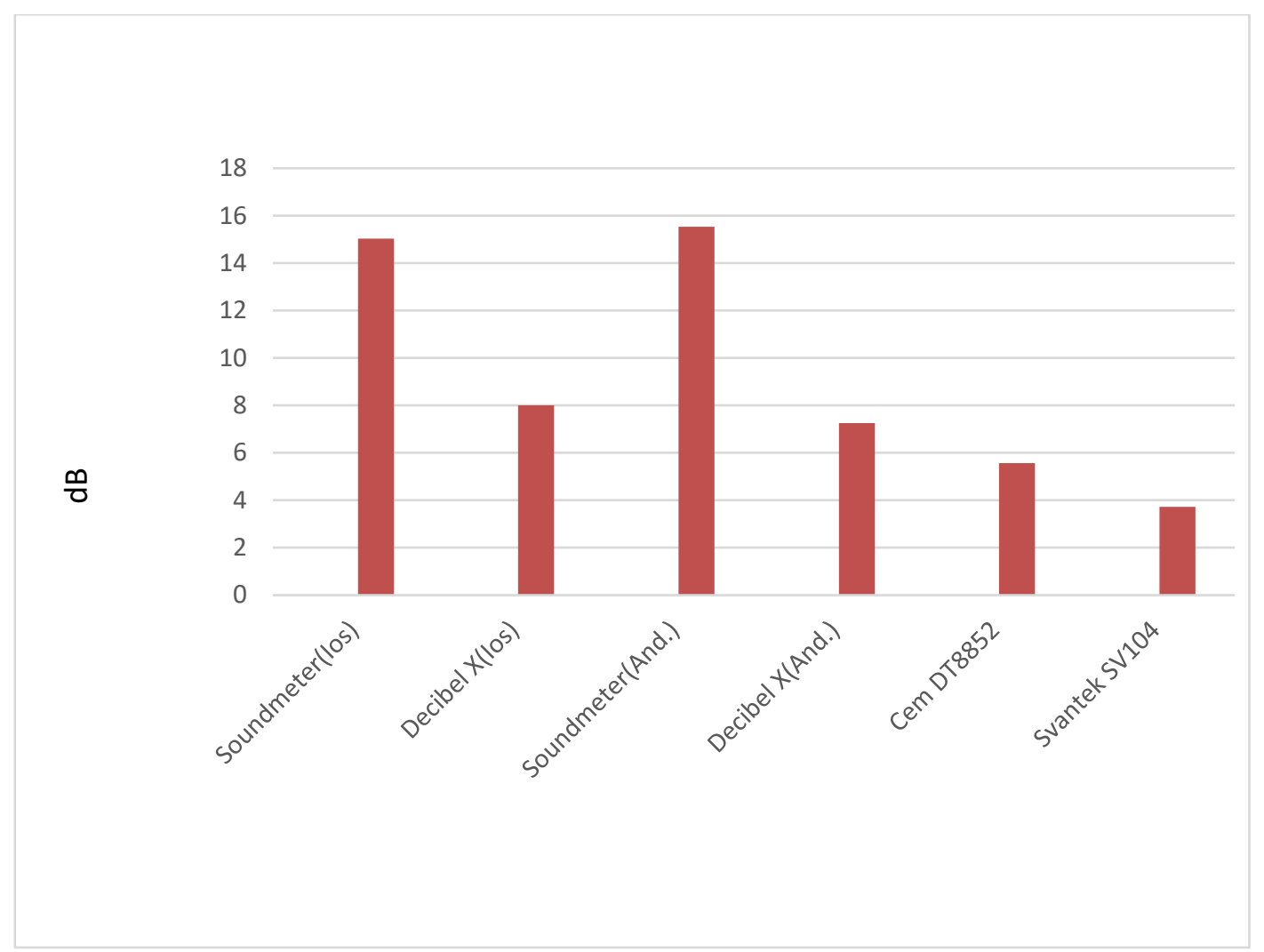

Figure 4. Sound measurement data inside the isolation box.

Looking at Figure 4, certain sound intensities observed in all measurement methods. The lowest sound value observed in Svantek SV104 and the highest sound value observed in android-based phone's applications. The sound values obtained from both ios and android based phones are quite different compared to commercial sound meters. This undermines the reliability of the measurements with the applications on the phone.

The conventional measurement uncertainties of ios and android based mobile phones were obtained. In accordance with the international standards, the metrological measurement uncertainty of a measure/instrument can be examined in two parts as total uncertainty $U_{T}$ (equation 6) and general uncertainty $\mathrm{U}_{\mathrm{G}}$ (equation 7) (Anonymous, 2013a; Damasceno \& Couto, 2018).

$$
\begin{gathered}
U_{T}=\mp \sqrt{U_{0}^{2}+U_{R}^{2}+U_{\text {ref }}^{2}} \\
U_{G}=\mp k \cdot U_{T} \text { (Coverage factor } ; k=2 \text {, for } 95 \% \text { reliability) }
\end{gathered}
$$

Where, $\mathrm{U}_{0}$; uncertainty due to the scale of the measuring device, $\mathrm{U}_{\mathrm{R}}$; uncertainty due to repeatability due to device / observer, $\mathrm{U}_{\text {ref; }}$, uncertainty of the device used as reference.

Also, the $\mathrm{U}_{0}$ value is calculated as follows (Bell, 2001);

$$
U_{0}=\frac{1}{\sqrt{3}} \cdot S(S ; \text { smallest scale value })
$$

In this study, The $U_{R}$ values are given as the standard deviation of measurements taken at different locations.

In measurement uncertainty calculations, $S=1$ (smallest scale value of the measurement), coverage factor $\mathrm{k}=2$ (\%95), and reference device uncertainty $\pm 0.5 \mathrm{~dB}$ (Cem DT8852 device's uncertainty) were used. Measurement uncertainties of ios and android based phones calculated according to different regions are given in Table 2. 
The average general uncertainties of the ios-based and android-based phones were calculated as $\pm 4.5 \mathrm{~dB}$ and $\pm 5 \mathrm{~dB}$, respectively (Table 2 ). These values can be considered higher than commercial sound measurement devices.

The correlations between measurement areas and measurement devices (Iphone 7+, Samsung Note8, Cem DT8852, Svantek SV104) are given in Table 3.

A negative correlation was observed with respect to $s$ values in all measurement areas (Table 3). Therefore, it can be said that there is an inverse relationship between I and s. In addition, the relationship between the sound intensities measured by the devices in different measurement areas is shown in Figure 5.

Since there are huge differences in I values, logarithmic scale is used for I values in this graph (Figure 5). It is observed that there is a bigger difference between iphone and Samsung results, if a normal scale graphic is drawn. However, Cem and Svantek values are like each other.

Table 2. $\mathrm{U}_{\mathrm{T}}$ and $\mathrm{U}_{\mathrm{G}}$ uncertainty values of ios and android based mobile phones.

\begin{tabular}{|c|c|c|c|c|c|c|}
\hline \multicolumn{7}{|c|}{$\mathrm{U}_{\mathrm{T}}($ Total measurement uncertainty, $\pm \mathrm{dB})$} \\
\hline & & Entrance & $\begin{array}{l}\text { Canteen/Dining } \\
\text { Hall }\end{array}$ & $\begin{array}{l}\text { Park/Resting } \\
\text { Area }\end{array}$ & Classroom & Laboratory \\
\hline \multirow{2}{*}{$\begin{array}{l}\text { Ios (Iphone } \\
7+)\end{array}$} & Soundmeter & 2.1 & 1.7 & 2.4 & 2.3 & 2.4 \\
\hline & Decibel X & 1.6 & 1.9 & 3.0 & 2.5 & 2.1 \\
\hline \multirow{2}{*}{$\begin{array}{l}\text { Android } \\
\text { (Samsung } \\
\text { Note8) }\end{array}$} & Soundmeter & 3.1 & 1.5 & 1.4 & 2.4 & 2.9 \\
\hline & Decibel X & 2.0 & 1.9 & 1.9 & 2.5 & 2.2 \\
\hline \multicolumn{7}{|c|}{$\mathrm{U}_{\mathrm{G}}($ General measurement uncertainty, $\pm \mathrm{dB})$} \\
\hline & & Entrance & $\begin{array}{l}\text { Canteen/Dining } \\
\text { Hall }\end{array}$ & $\begin{array}{l}\text { Park/Resting } \\
\text { Area }\end{array}$ & Classroom & Laboratory \\
\hline \multirow{2}{*}{$\begin{array}{l}\text { Ios (Iphone } \\
7+)\end{array}$} & Soundmeter & 4.3 & 3.4 & 4.9 & 4.6 & 4.9 \\
\hline & Decibel X & 3.2 & 3.9 & 6.0 & 5.1 & 4.3 \\
\hline \multirow{2}{*}{$\begin{array}{l}\text { Android } \\
\text { (Samsung } \\
\text { Note8) }\end{array}$} & Soundmeter & 6.1 & 3.1 & 2.7 & 4.7 & 5.9 \\
\hline & Decibel X & 4.0 & 3.8 & 3.8 & 4.9 & 4.5 \\
\hline
\end{tabular}

Table 3. Correlation values between measurement area sound intensities (I) and measurement devices cross sectional surface areas (s).

\begin{tabular}{lllllll}
\hline & Entrance & $\begin{array}{l}\text { Canteen/Dining } \\
\text { Hall }\end{array}$ & $\begin{array}{l}\text { Park/Resting } \\
\text { Area }\end{array}$ & Classroom & Laboratory & $\begin{array}{l}\text { Isolation } \\
\text { Box }\end{array}$ \\
\hline $\begin{array}{l}\text { Correlation } \\
\text { value }\end{array}$ & -0.59488 & -0.63939 & -0.632 & -0.70277 & -0.53053 & -0.41199 \\
\hline
\end{tabular}

In Table 4, ANOVA (analysis of variance) values of all measurement method performance according to the areas are given.

$\mathrm{P}$ value is less than 0.001 , therefore, it can be said that there is a very high significant difference between the measurement areas and the measurement device performance.

Table 4. Anova values of all measurement method according to areas.

\begin{tabular}{lcccccc}
\hline \multicolumn{1}{c}{ Source of Variance } & SS & df & MS & F & P-value & F ratio \\
\hline Between groups & 2646.503 & 5 & 529.3007 & 6.08629 & 0.000895 & 2.620654 \\
\hline Inside groups & 2087.185 & 24 & 86.96606 & & & \\
\hline Total & 4733.689 & 29 & & & & \\
\hline
\end{tabular}




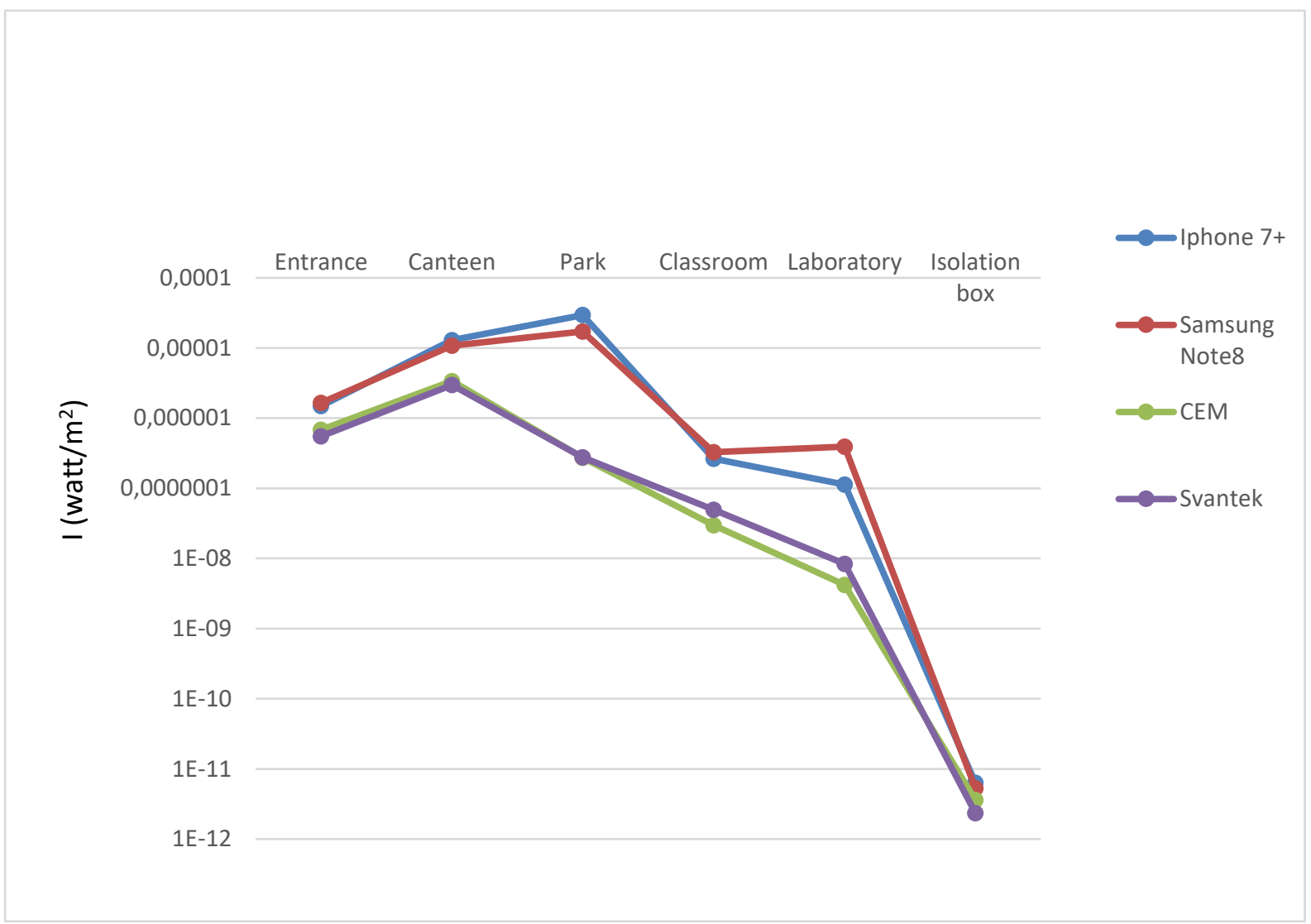

Figure 5. Relationship between I and measurement devices in log scale.

\section{Conclusion}

In this study, ios and android based sound measurement applications and commercial sound measurement devices were compared. Sound measurements were taken from indoor and outdoor locations. All measurements taken instantaneously. Ios based iphone 7+ device, and android based samsung note8 smart mobile phones were used. Soundmeter and Decibel X mobile applications were selected to measure environment sound with phones. In addition, environment sound measurements were obtained with commercially available devices that named Cem DT8852 and Svantek SV104. These commercial devices were calibrated, and their measurements are internationally traceable.

Sound intensity measurements were calculated using relevant equations for both phone applications and commercial devices. In addition to this, for each measurement area, the sound energy, power, and sound pressure variation calculated. The relationship between telephone applications and commercial sound measuring devices discussed, also the relationships between sound intensity and measurement environments evaluated.

According to the obtained results, the following determinations can be written;

The environment noise/sound was obtained in $\mathrm{dB}$ unit using all measurement methods. Since sound intensity obtained instantaneously, all measurement methods could be compared.

In the environment sound measurements, the highest sound intensity was obtained in the park/resting area. All measurement methods showed the same result. However, sound measurement values recorded with cell phones were obtained higher than others.

Commercial devices recorded almost identical results in environment sound measurements. Since these devices calibrated, they can be defined as reference devices for environment sound measurements and can be used anywhere for all sound measurements.

A sound-isolated box was designed to evaluate the difference in recording sound in a quiet environment for each measurement method. Soundmeter application, which is a mobile phone 
application, showed the highest value in sound measurements performed in the box. However, the other mobile application, Decibel X, recorded a sound intensity value of almost half. Sound measurements recorded with mobile phone applications in a solation box can be called whisper-level audio data. On the other hand, almost no sound was recorded with commercial sound measurement devices. In this case, it can be said that there is electronic noise in a quiet environment for mobile phone applications. These electronic noises are about $13 \mathrm{~dB}$, and $7 \mathrm{~dB}$ for soundmeter and decibel $\mathrm{x}$, respectively.

Since the sound recorded with different measurement methods in the same measurement areas, the correlations between these measurement areas and the measurement methods were evaluated and it was calculated to be negative. Therefore, it can be said that there is an inverse relationship between the measurement environment and measurement methods.

The relationship between the measured sound intensity and the measurement cross-section surface area used in each measurement method was examined. The highest sound intensity was achieved with the iphone $7+$ in the park location. On the other hand, commercial devices measured the same level of sound intensity as each other.

In addition, Anova analysis was carried out with measurement methods in the measurement areas. It can be said that there is a highly significant difference between measurement methods and measurement areas.

In general, it can be said that there is an average of 5\% difference between the soundmeter application and the Decibel $\mathrm{X}$ application in sound measurements recorded by mobile phones. Soundmeter application measured higher sound intensity values in the same environment. On the other hand, commercial devices recorded almost the same sound intensity values in the same environment. Compared to these commercial devices, mobile phone applications showed an average of 10-20\% difference measurement of sound intensity. Both ios and android based applications measured higher volume values between $10-20 \%$. The general uncertainty values of mobile phones are found as $\pm 4,5 \mathrm{~dB}$, and $\pm 5 \mathrm{~dB}$, for iphone $7+$ and samsung note 8 , respectively. These values can be considered higher than commercial sound meters.

In this study, sound intensity data were obtained in indoor and outdoor environments with different mobile phone applications and commercial sound measuring devices. It is concluded that mobile phone applications are not reliable enough. In addition, it was observed that common areas (such as park and canteen) are very close to the maximum sound intensity limit according to the international standard.

By means of the developing technology, only an idea can be obtained with mobile phone sound measurement applications that can be accessed by almost everyone, however, it is thought that these devices cannot be used for a scientific measurement.

\section{References}

ANSI. (2007). ANSI S1.4-1983, Specification for Sound Level Meters, American National Standards Institute, New York.

Anonymous, (2013a). Expression of the Uncertainty of Measurement in Calibration. EA-European Cooperation for Accreditation, EA-4/0. https://european-accreditation.org/wpcontent/uploads/2018/10/ea-4-02-m-rev01-september-2013.pdf Accessed time 25.01.2021.

Anonymous, (2013b). European environment agency report. Environmental indicator report. http://www.eea.europa.eu/publications\#c $7=e n \& c 11=5 \& \mathrm{c} 14=\& \mathrm{c} 12=\& \mathrm{~b} \_$start $=0$ Accessed time 25.01.2021.

Bell, S. (2001). A Beginner's Guide to Uncertainty of Measurement, issue2, (pp.13-15), Crown, UK, HMSO.

Damasceno , J.C. \& Couto, P.R.G. (2018). Methods for Evaluation of Measurement Uncertainty, (C2), IntechOpen, Open Access Books. doi:10.5772/intechopen.74873

D'Hondt, E., Stevens, M., \& Jacobs, A. (2013). Participatory noise mapping works! An evaluation of participatory sensing as an alternative to standard techniques for environmental monitoring. Pervasive Mobile Computing, 9, 681-94. doi:10.1016/j.pmcj.2012.09.002

Kanhere, S.S. (2013). Participatory sensing: Crowdsourcing data from mobile smartphones in urban space. Distributed computing and internet technology. ICDCIT 2013. Lecture Notes in 
Computer Science, (pp.19-26). Berlin, Germany: Springer. doi:10.1007/978-3-642-360718_2Springer.

Kanjo, E. (2010). NoiseSPY: A Real-time mobile phone platform for urban noise monitoring and mapping. Mobile Networks and Applications, 15, 562-574. doi:10.1007/s11036-009-0217-y

Kardousb, C.A., \& Shaw P.B., (2014). Evaluation of smartphone sound measurement applications. The Journal of the Acoustical Society of America, 135 (4), ELI186. doi:10.1121/1.4865269

Maisonneuve, N., Mathias, N., \& Ochab, B. (2010). Participatory noise pollution monitoring using mobile phones. Information Polity, 15, 51-71. doi:10.3233/IP-2010-0200

Maisonnuve, N., Stevens, M., Niessen, M.E., Haneppe, P., \& Steels, L. (2009). Citizen noise pollution monitoring. Proceedings of the $10^{\text {th }}$ annual international conference on digital government research: social networks. Digital Government Society of North America, 96-103.

May, J.J. (2000). Occupational hearing loss. American Journal of Industrial Medicine , 37(1), 112-20. doi:10.1002/(SICI)1097-0274(200001)37:1<112::AID-AJIM9>3.0.CO;2-\%23

Mazda, F. (1993). Telecommuniciations Engineer's Reference Book, (S8.4). USA, ButterworthHeinemann.

Murphy, E., \& King, A. (2016). Testing the accuracy of smartphones and sound level meter applications for measuring environmental noise. Applied Acoustics, 106, 16-22. doi:10.1016/j.apacoust.2015.12.012

NIOSH. (1998). Criteria for a Recommended Standard, Occupational Noise Exposure. Public no.98126. Ohio.

O'malley, V., King, E., Kenny, L., \& Dilworth, C. (2009). Assessing methodologies for calculating road traffic noise levels in Ireland - Converting CRTN indicators to the EU indicators ( $\left.\mathrm{L}_{\mathrm{den}}, \mathrm{L}_{\mathrm{night}}\right)$. Applied Acoustics, 70, 284-296. doi:10.1016/j.apacoust.2008.04.003

OSHA. (2013). OSHA 1683 standard. http://www.osha.gov/dts/osta/otm/new noise Accessed time 25.01.2021.

Pienkowski, M., Munguia, R., \& Eggermont, J.J. (2013). Effects of passive, moderate-level sound exposure on the mature auditory cortex: Spectral edges, spectrotemporal density, and real-world noise. Hearing Research, 296, 121-130. doi:10.1016/j.heares.2012.11.006

Serway, R., Beichner, R., \& Jewett, J. (1999). Physics for Scientists and Engineers, $5^{\text {th }}$ edition, (pp. 520535). Boston, USA: Brooks cole.

Serway, R., \& Jewett, J., (2010). Physics for Scientists and Engineers with Modern Physics, $10^{\text {th }}$ edition, (pp. 507-522). Boston, USA: Brook cole.

Sheppard, A., Ralli, M., Gilardi, A., \& Salvi, R. (2020). Occupational Noise: Auditory and NonAuditory Consequences. International Journal of Environmental Research and Public Health, 17(23), 8963. doi:10.3390/ijerph17238963

Sriwattanatamma, P., \& Breysse, P. (2000). Comparison of NIOSH noise criteria and OSHA hearing conservation criteria. American Journal of Industrial Medicine, 37,334-338. doi:10.1002/(SICI)1097-0274(200004)37:4<334::AID-AJIM2>3.0.CO;2-Z

Sun, D.W., Wang, B., Guo, H., Wang, N., Gao, D., \& Zhu, B. (2021). Single nucleotide polymorphisms in JNK1 are associated with susceptibility to noise-induced hearing loss in a Chinese population. International Archives of Occupational and Environmental Health, Accepted paper. doi:10.1007/s00420-020-01644-0

TSE. (2014). Turkish Standards Institution TSE 61672-1 standard. http://intweb.tse.org.tr/Standard/Standard/Standard.aspx?081118051115108051104119110104 $\underline{055047105102120088111043113104073083065084050121081083112073117103}$ Accessed time 27.01.2021.

TOG. (2012). Turkish 6331 no, Occupational health and safety law. Turkish Official Gazette. http://www.mevzuat.gov.tr/mevzuat?MevzuatNo=6331\&MevzuatTur=1\&MevzuatTertip $=5$ Accessed time 25.01.2021.

Young, H., \& Freedman, R. (2011). Sears\&Zemansky University Physics, V1, $10^{\text {th }}$ edition, (pp. 521540). Melbourne, USA: Addison Wesley.

Young, H, Freedman, R., \& Ford, L. (2013). Sears\&Zemansky University Physics with Modern Physics, $13^{\text {th }}$ edition, (pp. 488-510). Melbourne, USA: Addison Wesley. 